\title{
Urinary Concentrating Ability and Growth Failure in Urinary Tract Disorders
}

\author{
W. S. UTTLEY, JANE PAXTON, and D. THISTLETHWAITE \\ From the Department of Child Life and Health, University of Edinburgh, and the Royal Hospital for Sick Children, \\ Edinburgh
}

Uttley, W. S., Paxton, J., and Thistlethwaite, D. (1972). Archives of Disease in Childhood, 47, 436. Urinary concentrating ability and growth failure in urinary tract disorders. Results of a pitressin concentration test are described in 50 control patients and 63 patients with urinary tract infection and/or hydronephrosis. In affected cases the test was unable to predict either the presence of significant radiological abnormalities or likely recurrence of infection and is not thought to be a reliable discriminator between renal and lower urinary tract infection. In 37 cases maximal urinary concentration correlated with endogenous creatinine clearance. It is proposed that artificially-fed infants with urinary tract infection and hydronephrosis may have a concentration defect of such severity as to preclude a normal caloric intake.

The vulnerability of the renal medulla in hydronephrosis and urinary tract infection with resultant impairment of urinary concentrating ability has been well documented (Berlyne, 1961; Kaitz, 1961). Yet, apart, from the studies of Winberg (1959b), these aspects have received little attention in the paediatric literature. We have adapted a pitressin concentration test designed to be carried out at ward level and not to be upsetting to children, for the investigation of patients with urinary tract infection and/or hydronephrosis with the aim of assessing its usefulness as a routine procedure. The following report correlates our results with other clinical and functional findings, and analyses the effects of impaired urinary concentration on growth and development.

Methods
Concentration test. Patients taking a normal ward
diet were allowed no fluids after the evening meal at
18.00 hours on the day preceding collections. In the
case of infants the 22.00 hours feed was given and
fluids discontinued thereafter. The bladder was emptied
naturally at approximately 06.00 hours on the day of the
test and the sample obtained designated 'pre-pitressin'.
A standard dose of $0 \cdot 1 \mathrm{IU} / \mathrm{kg}$ body weight of pitressin
tannate in oil was administered intramuscularly by a
tuberculin syringe, the vial having been prewarmed.
Children were encouraged to empty the bladder at

Received 8 November 1971. hourly intervals, and the procedure was terminated with a final collection after 4 hours.

Osmolality was determined on $0.2 \mathrm{ml}$ samples using the 'Advanced' osmometer and the highest value obtained over the 4-hour post-pitressin period designated 'maximal'.

Control values for the test were obtained from 50 children aged 2 to 12 years who were being investigated for enuresis or frequency. All patients had three or more negative urine cultures and normal serum urea and electrolytes. All children had a normal intravenous pyelogram.

Investigations were done on 63 patients aged 3 months to 12 years, either suffering from or with a history of urinary tract infection. They were unselected, consisting of such cases admitted to one medical unit at the Royal Hospital for Sick Children, Edinburgh, between January 1969 and June 1971. Criteria for diagnosis of urinary tract infection were based on the finding of more than $10^{5}$ bacteria per $\mathrm{ml}$ on a clean passed specimen or evidence of bacteriuria on suprapubic aspiration. All children were investigated radiologically by both excretion urography and by micturating cystourethrography. Patients were divided into three groups: Group I. Cases of urinary tract infection without abnormality on intravenous pyelogram or micturating cystourethrogram. Group II. Cases of urinary tract infection associated with significant radiological abnormalities suggesting the possibility of renal medullary involvement, i.e. hydronephrosis, calyectasis, scarring, or reflux into the pelvis with distension. Group III. Criteria as Group II but no infection during the previous 3 weeks. 


\section{Urinary Concentrating Ability and Growth Failure in Urinary Tract Disorders}

Creatinine clearances. Endogenous creatinine clearances were estimated on 24-hour collections of urine obtained within 72 hours of the concentration test. Serum was absorbed by Lloyd's reagent and creatinine measured by the method of King and Wootton (1956). Clearance values were corrected by tables for surface area.

Growth status. Height or length of infants was measured with a frame. Scores for height and weight were obtained as the number of SDs from the mean for appropriate age and sex on the basis of charts produced by the Department of Child Life and Health, University of Edinburgh, for normal Edinburgh children.

\section{Results}

Control patients. Maximal urinary concentration achieved by the 50 control children aged 2 to 12 years was $1029 \pm 130 \mathrm{SD} \mathrm{mOsm} / \mathrm{kg}$ (range 769 to 1388), the values having a normal distribution. There was no significant correlation with age $(r=0 \cdot 12)$. The average rise over the prepitressin value was $166 \mathrm{mOsm} / \mathrm{kg}$ in 41 patients.

Patients with infection and hydronephrosis. The 63 children with urinary tract problems had a mean concentrating ability of $785 \pm 240 \mathrm{SD}$ $\mathrm{mOsm} / \mathrm{kg}$ (range 215 to 1222 ), and an analysis of their distribution is shown in Table I where all groups can be seen to have a mean value for the test significantly less than the controls at the $1 \%$ level. Clinical and biochemical details of 8 cases who were found to have a severe concentrating defect $(<500 \mathrm{mOsm} / \mathrm{kg})$ are shown in Table II.

Results of endogenous creatinine clearances were available in 37 patients, 29 of whom had hydronephrosis. There was a positive correlation significant at the $1 \%$ level between maximal urinary concentration and creatinine clearance $(r=0.61$, $y=4 \cdot 3 x+333$ ). Exclusion of the 8 cases without hydronephrosis did not materially affect either the correlation coefficient or the regression equation. The scattergram of these values is represented by Fig. 1 upon which a line of proportionate functional impairment has been added. This line has been theoretically derived to represent a directly proportionate impairment of glomerular filtration as compared with concentrating ability. It passes through a point representing average normal values for GFR and maximal concentration (120 $\mathrm{ml} /$ minute per $1.73 \mathrm{~m}^{2}, 1030 \mathrm{mOsm} / \mathrm{kg}$ ) and a point of absolute impairment $\left(\mathrm{GFR}=0, \mathrm{C}_{\mathrm{H}_{2} \mathrm{o}}=0\right.$ ).

Growth status. Of the 8 children with severe impairment of urinary concentration, 6 , as shown in Table II, were failing to thrive in that either their height or weight was $2 \mathrm{SD}$ or more below the expected for age, compared with 3 of the remaining 55 patients studied. As the majority of these children were under the age of 3 years (6 cases, average age 14.3 months, range 3-30 months), they formed a group for whom we were ethically unable to obtain normal control values for urinary concentration. Their height status has been plotted against maximal urinary concentration in Fig. 2, along with the results obtained from all other children studied under the age of 3 years (9 children, average age 18.5 months, range 5-34). There is a correlation significant at the 0.05 level $(r=0.72, y=0.005 x-4.0)$. There were no significant correlations between height or weight and $\mathrm{BUN}, \mathrm{CO}_{2} \mathrm{CP}$, and $\mathrm{Cr}$.

Follow-up studies. Repeat determinations of concentrating ability were carried out in 12 patients -4 controls and 8 patients-within 72 hours.

TABLE I

Distribution of Maximal Urinary Concentrations (mOsm $/ \mathrm{kg})$ in 63 Children with Urinary Tract Disease by Groups

\begin{tabular}{|c|c|c|c|c|c|c|c|}
\hline & & \multicolumn{4}{|c|}{ Maximal Concentration After Pitressin } & \multirow{2}{*}{$\begin{array}{l}\text { Total Patients } \\
\text { in Groups }\end{array}$} & \multirow{2}{*}{$\begin{array}{l}\text { Mean } \pm \text { SD } \\
\text { of Group Total }\end{array}$} \\
\hline & & $<500$ & $500-750$ & $750-1000$ & $>1000$ & & \\
\hline \multicolumn{2}{|l|}{ Group I } & 0 & 6 & 11 & 7 & 24 & $884 \pm 193$ \\
\hline Group II & $\left\{\begin{array}{l}\text { Unilateral anomaly } \\
\text { Bilateral anomaly } \\
\text { Total }\end{array}\right.$ & $\begin{array}{l}1 \\
4 \\
5\end{array}$ & $\begin{array}{l}3 \\
1 \\
4\end{array}$ & $\begin{array}{l}9 \\
0 \\
9\end{array}$ & $\begin{array}{l}1 \\
0 \\
1\end{array}$ & 19 & $675 \pm 251$ \\
\hline Group III & $\left\{\begin{array}{l}\text { Unilateral anomaly } \\
\text { Bilateral anomaly } \\
\text { Total }\end{array}\right.$ & $\begin{array}{l}0 \\
3 \\
3\end{array}$ & $\begin{array}{l}2 \\
4 \\
6\end{array}$ & $\begin{array}{l}7 \\
0 \\
7\end{array}$ & $\begin{array}{l}2 \\
2 \\
4\end{array}$ & 20 & $770 \pm 240$ \\
\hline \multicolumn{2}{|c|}{ All groups: Total } & 8 & 16 & 27 & 12 & 63 & $785 \pm 240$ \\
\hline
\end{tabular}


TABLE II

Further Details of 8 Cases Who Failed to Achieve Maximal Urinary Concentration of $500 \mathrm{mOsm} / \mathrm{kg}$

\begin{tabular}{|c|c|c|c|c|c|c|c|c|c|c|}
\hline \multirow{2}{*}{ Case No. } & \multirow{2}{*}{ Sex } & \multirow{2}{*}{ Age } & \multirow{2}{*}{$\begin{array}{c}\text { Maximal } \\
\text { Urinary } \\
\text { Concentration } \\
(\mathbf{m O s m} / \mathbf{k g})\end{array}$} & \multicolumn{2}{|c|}{$\begin{array}{l}\text { No. of SDs } \\
\text { from Normal }\end{array}$} & \multirow{2}{*}{$\begin{array}{c}\text { Radiological } \\
\text { Abnormalities } \\
\text { Seen on } \\
\text { IVP and MCU }\end{array}$} & \multirow{2}{*}{$\begin{array}{l}\mathrm{Ccr} \mathrm{ml} ! \\
\text { min per } \\
1 \cdot 73 \mathrm{~m}^{2}\end{array}$} & \multirow{2}{*}{$\begin{array}{c}\text { BUN } \\
(\mathrm{mg} / 100 \mathrm{ml})\end{array}$} & \multirow{2}{*}{$\begin{array}{c}\mathrm{CO}_{2} \mathrm{CP} \\
(\mathrm{mEq} / 1 .)\end{array}$} & \multirow{2}{*}{$\begin{array}{c}\text { Serum } \\
\text { Osmolality } \ddagger \\
\text { (mOsm/kg) }\end{array}$} \\
\hline & & & & Height & Weight & & & & & \\
\hline \multirow{2}{*}{$\underset{1}{\text { Group } I I}$} & & & & & & & & & & \\
\hline & F & $1 \mathrm{yr}$ & 408 & $-2 \cdot 6$ & $-4 \cdot 7$ & $\begin{array}{l}\text { Left duplex kidney } \\
\text { with reflux and } \\
\text { hydronephrosis }\end{array}$ & 40 & 17 & 18 & 290 \\
\hline $\begin{array}{l}2 \\
3\end{array}$ & $\begin{array}{l}\mathbf{F} \\
\mathbf{F}\end{array}$ & $\begin{array}{l}3 \mathrm{mth} \\
5 \mathrm{mth}\end{array}$ & $\begin{array}{l}215 \\
391\end{array}$ & $\begin{array}{l}-2 \cdot 0 \\
-3 \cdot 2\end{array}$ & $\begin{array}{l}-1 \cdot 9 \\
-4 \cdot 0\end{array}$ & $\begin{array}{l}\text { Bilateral hydronephrosis } \\
\text { Bilareral hydronephrosis } \\
\text { and reflux }\end{array}$ & $\begin{array}{l}45 \\
56\end{array}$ & $\begin{array}{l}24 \\
45\end{array}$ & $\begin{array}{l}18 \\
15\end{array}$ & $\begin{array}{l}288 \\
292\end{array}$ \\
\hline 4 & $\mathbf{M}$ & $1 \mathrm{yr}$ & 401 & $-5 \cdot 1$ & $-3 \cdot 0$ & Bilateralhydronephrosis & 72 & 27 & 18 & 293 \\
\hline $5 *$ & $\mathbf{F}$ & $6 \mathrm{yr}$ & 323 & $-3 \cdot 2$ & $-1 \cdot 1$ & $\begin{array}{l}\text { Bilateral hydronephrosis } \\
\text { with staghorn calculi }\end{array}$ & 54 & 20 & 25 & 296 \\
\hline \multirow{2}{*}{$\underset{6}{\text { Group }} I I I$} & & & & & & & & & & \\
\hline & $\mathbf{M}$ & $2 \mathrm{yr}$ & 328 & $-2 \cdot 0$ & $-2 \cdot 2$ & $\begin{array}{l}\text { Bilateral hydronephrosis } \\
\text { and reflux }\end{array}$ & 14 & 90 & $23 t$ & 314 \\
\hline 7 & $\mathbf{M}$ & $8 \mathrm{yr}$ & 250 & -0.9 & $0 \cdot 0$ & $\begin{array}{l}\text { Bilateral hydronephrosis } \\
\text { and reflux }\end{array}$ & 26 & 39 & 22 & 296 \\
\hline 8 & $\mathbf{M}$ & $2 \mathrm{yr}$ & 386 & $-1 \cdot 7$ & -0.2 & $\begin{array}{l}\text { Bilateral hydronephrosis } \\
\text { with staghorn calculi }\end{array}$ & 112 & 15 & 22 & 304 \\
\hline
\end{tabular}

$\star$ Patient with spina bifida cystica (repaired).

tReceived alkali supplements for renal rickets.

$\ddagger$ Normal in children without concentrating defects $287 \pm 5.5 \mathrm{mOsm} / \mathrm{kg}$ (28 cases).

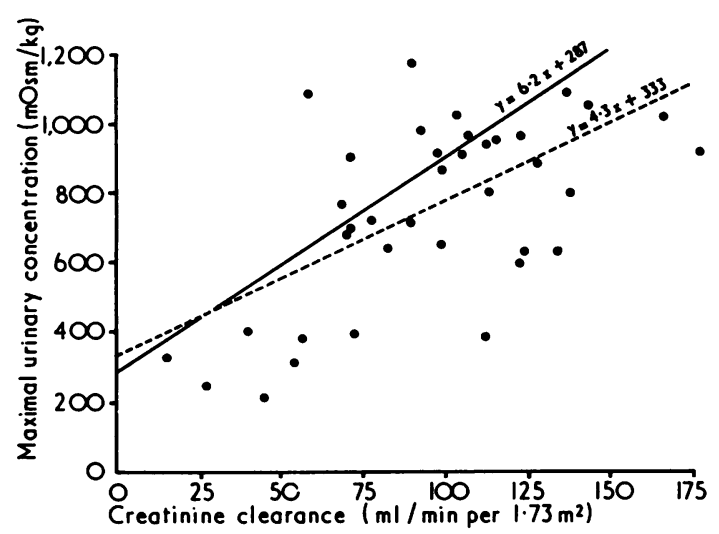

FIG. 1.-Relation (between maximal urinary concentration and $C$ cr) in 37 patients with urinary tract infection and/or hydronephrosis $(r=0 \cdot 61 \cdot y=4 \cdot 3 x+333)$, with theoretical line of proportionate functional impairment superadded.

The error of the method (SD of differences $/ \sqrt{ } 2$ ) was $50 \mathrm{mOsm} / \mathrm{kg}$ or $4.9 \%$.

Cases 1 to 4 of Table II were reassessed after control of their infection, and alterations in their growth status and biochemical measurements are shown in Table III.

Forty-eight patients were followed up for an average period of 10 months (range 3-24). There was no relation between recurrence of infection and an inability to concentrate the urine to above $750 \mathrm{mOsm} / \mathrm{kg}$.

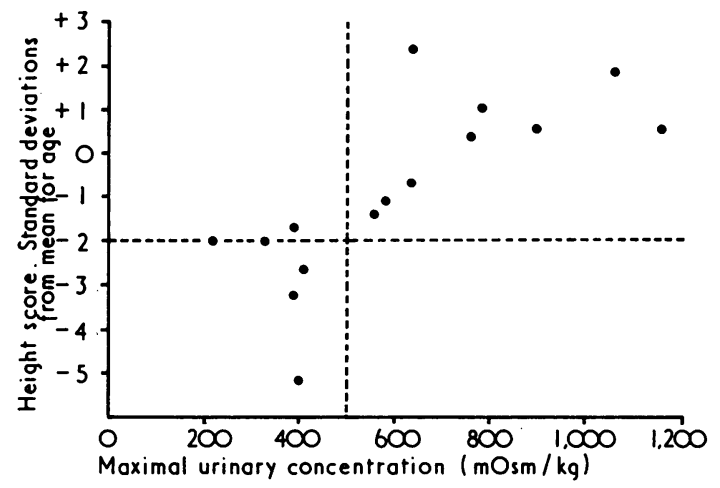

Fig. 2.-Relation between height score and maximal urinary concentration in 15 children aged 3 to 34 months with urinary tract infection and/or hydronephrosis $(r=0 \cdot 72, y=0.005 x-4 \cdot 0)$.

Average urinary osmolality in normal infants. 24-hour collections of urine were obtained from 9 healthy infants-average age $6 \cdot 7$ months (range 3-18)-who were taking a normal formula or toddler diet. The mean concentration was $652 \mathrm{mOsm} / \mathrm{kg}$ (range 437-1029).

\section{Discussion}

Control values for maximal concentration were identical with results obtained by Winberg (1959a) 
TABLE III

Changes on Follow-up After Eradication of Infection in Measurements of Four Patients Aged Under 3 Years at Onset Who Had Severe Impairment of Urinary Concentration and Failure-to-Thrive

\begin{tabular}{|c|c|c|c|c|}
\hline & Case 1 & Case $2^{\star}$ & Case 3 & Case 4 \\
\hline $\begin{array}{l}\text { Follow-up (mth) } \\
\text { Maximal concentration (mOsm/kg) } \\
\text { Height score for appropriate age SD } \\
\text { Weight score for appropriate age SD } \\
\text { BUN (mg/100 ml) } \\
\mathrm{CO}_{2} \mathrm{CP}(\mathrm{mEq} / \mathrm{l} \text {.) }\end{array}$ & $\begin{array}{r}8 \\
+642 \\
+1 \cdot 9 \\
+3 \cdot 1 \\
-8 \cdot 0 \\
+6 \cdot 8\end{array}$ & $\begin{array}{r}25 \\
+659 \\
-0.4 \\
+0 \cdot 2 \\
-10 \cdot 3 \\
+3 \cdot 9\end{array}$ & $\begin{array}{l}4 \\
-6 \\
-0 \cdot 1 \\
-0 \cdot 2 \\
-19 \cdot 7 \\
+2 \cdot 7\end{array}$ & $\begin{array}{r}12 \\
+473 \\
+1 \cdot 6 \\
+1 \cdot 5 \\
-4 \cdot 0 \\
-2 \cdot 8\end{array}$ \\
\hline
\end{tabular}

^Patient developed obstructive hydrocephalus after hyperosmolar episode.

and Edelmann et al. (1967) where different techniques were used. The lower limit of normal, $750 \mathrm{mOsm} / \mathrm{kg}$, agrees with Kerr (1968), and a figure of $<500 \mathrm{mOsm} / \mathrm{kg}$ would represent severe impairment.

Renal function in infection and hydronephrosis. Winberg (1959b) showed renal parenchymal infection to be associated with reduced concentration. He showed this to be a temporary phenomenon with improvement some 4 to 8 weeks after eradication of the infection. Of the 22 cases which he investigated, only 2 are recorded as having radiological abnormalities, yet 17 showed impairment of concentrating ability. This is in contradistinction to our own results where 6 of 24 cases with infection of structurally normal urinary tracts showed similar impairment.

These discrepancies suggest that urinary concentration is not a reliable discriminator between upper and lower urinary tract infection as has often been assumed, and such discrimination requires the bladder washout technique of Fairley et al. (1967) or, in the event of Esch. coli infection, determination of serum antibodies (Brumfitt and Percival, 1964).

Results obtained in patients with hydronephrosis (Table I, Groups II and III) also show conclusively that urinary concentration is a poor guide to the presence or absence of radiological abnormalities, even though all patients with severe concentration defects had long-standing structural anomalies.

The correlation between urinary concentration and $\mathrm{C}^{\mathrm{cr}}$, and the proximity of its regression line to the theoretical line of proportionate impairment, indicate the disturbance of renal function in the cases studied to be of both glomerular and tubular nature, and are in keeping with the experimental findings of Suki et al. (1966) for chronic hydronephrosis in dogs. Maximal concentration thus appears a valid method of assessing renal function in such cases and should be of particular value in the long-term study of affected children.
Concentrating ability and growth. The incidence of growth failure in children with a severe concentrating defect, and the highly significant correlation between height status and maximal urinary concentration of Fig. 2 raised the possibility that such growth failure may have resulted from a concentration defect.

That hypocaloric dwarfism results from the concentration defect found in nephrogenic or untreated pitressin-sensitive diabetes insipidus appears to be generally accepted (Bergstrom, De Leon, and Van Gemund, 1964); yet the contribution to growth failure of a less severe concentration defect in children with other forms of renal disease has been neglected. West and Smith (1956) found 21 of 41 patients with chronic renal disease to be failing to thrive. All 21 cases had a failure of concentrating ability defined as a urinary concentration of not greater than SG 1.016 ( $=650$ mOsm from figures of Edelmann et al., 1967) in early morning specimens. As concentrating defects defined by these criteria were also found in patients who were not growth retarded, they concluded that poor urinary concentration played no part in such growth retardation. This was ascribed to the stunting effect of chronic acidosis plus a hypocaloric factor due to the appetite suppression of chronic renal disease.

Darrow and Pratt (1950) stated that the usual expenditure of water per 100 calories metabolized comprises $70 \mathrm{~cm}^{3}$ of insensible water loss and 80 $\mathrm{cm}^{3}$ of urine, the figures of 100 calories and 150 $\mathrm{cm}^{3}$ water representing, respectively, the caloric and fluid requirements per $\mathrm{kg}$ body weight in infancy. Thus human breast milk producing a solute load for urinary excretion of approximately $10 \mathrm{mOsm} / 100$ calories will contribute $125 \mathrm{mOsm} /$ $\mathrm{kg}$ to the final urinary concentration, whereas cow's milk derivatives with a solute load of approximately $40 \mathrm{mOsm} / 100$ calories (Metcoff, 1964) will contribute as much as $500 \mathrm{mOsm} / \mathrm{kg}$ to the final urinary concentration. 
The infants shown in Table II, none of whose maximal concentrating ability is much greater than $400 \mathrm{mOsm} / \mathrm{kg}$, will not be able to excrete the solute load produced by a normal formula or mixed diet and, unless given extra water, will tend to become hyperosmolar with resultant vomiting or refusal of feeds. Random estimations of serum osmolality in these patients were all at the upper end of the normal range or above, and confirm that they were barely able to maintain body homeostasis. Indeed, one of the cases (Case 2) was originally admitted in a state of hypernatraemic dehydration with a serum sodium of $161 \mathrm{mEq} / 1$. and sustained brain damage with resultant hydrocephalus. Further support for this hypothesis exists in the finding that the average urinary concentration over a 24-hour period in healthy infants of the same age range was greater than the maximum achieved by the abnormal children of Table II under conditions of fluid deprivation and pitressin administration.

Although breast-fed infants would be unaffected, it appears that the kidneys of artificially-fed infants with concentration defects of long standing such as we have decribed would be unable to handle the solute excretion of their formula diet, and unless given extra water or special low-solute feeds such infants would not achieve their normal caloric requirements. These physiological considerations will no longer be applicable if control of infection results in a significant increase in concentrating ability as confirmed by the follow-up data of Table III. The older child, by virtue of his ability to regulate his own fluid intake, will provide himself with the extra water required for solute excretion from a normal diet.

The concentrating ability of infants with structural renal disease requires to be investigated so that possible needs for extra water or low-solute feeds can be met. They will be particularly at risk during periods of pyrexial vomiting due to infection when the chance of a hyperosmolar episode will be increased.

No attempt has been made to differentiate the relative contributions of growth retardation, of acidosis, and of the hypocaloric element which we think may result at least partly from long-standing impairment of urinary concentrating ability, but this suggests itself as an area for further study.

\section{Conclusions}

The estimation of maximal urinary concentration has proved to be a safe and reproducible method of assessment of renal function. The range obtained in control patients was of such a width that a single estimation could not be relied upon to differentiate between renal as opposed to lower urinary tract infection in affected cases. Marked impairment of concentration is likely to be found in patients with severe radiological abnormalities and a comparable impairment of glomerular function. A normal concentrating ability cannot be relied upon to exclude significant structural abnormalities of the urinary tract and does not influence the liability to recurrence of infection. Nevertheless, normal values in cases with prolonged symptoms or radiological abnormalities are a reassuring finding as to renal function and should prove a useful method of assessing long-term progress in such cases. Indeed, the good correlations obtained with creatinine clearance suggest that the simpler concentration test is an equal screen to renal function in cases of infection and hydronephrosis in children.

Small infants on artificial feeds will have difficulty in maintaining body homeostasis in the face of severe concentration defects and are at risk from the developmnt of hyperosmolar episodes. If the defect has been present over a prolonged period, it will result in a failure of normal caloric intake which will contribute towards a failure to thrive. Thus concentration tests are indicated in cases of recurrent urinary tract infection and hydronephrosis as an index of renal function, and in infants and small children where the need for special provisions in management may be defined.

We wish to thank particularly Dr. J. D. Crombie, Department of Paediatric Biochemistry, Royal Hospital for Sick Children, and Miss A. Taylor and Mrs. S. Leadbetter, Department of Child Life and Health, University of Edinburgh, for technical assistance.

\section{REFERENCES}

Bergstrom, W. H., De Leon, A. S., and Van Gemund, J. J. (1964). Growth aberrations in renal disease. Pediatric Clinics of North America, 11, 563 (see p. 568).

Berlyne, G. M. (1961). Distal tubular function in chronic hydronephrosis. Quarterly fournal of Medicine, 30, 339.

Brumfitt, W., and Percival, A. (1964). Specific antibody response of patients with significant bacteriuria. In Proceedings of the 2nd International Congress of Nephrology, 1963 (Excerpta Medica International Congress Series, No. 78), p. 260 . Ed. by J. Vostál, and G. Richet. Excerpta Med. Foundation, Amsterdam.

Darrow, D. C., and Pratt, E. L. (1950). Fluid therapy: relation to tissue composition and the expenditure of water and electrolyte. Fournal of the American Medical Association, 143, 365.

Edelmann, C. M., Jr., Barnett, H. L., Stark, H., Boichis, H., and Soriano, J. R. (1967). A standard test of renal concentration capacity in children. American Fournal of Diseases of Children, 114, 639.

Fairley, K. F., Bond, A. G., Brown, R. B., and Habersberger, P (1967). Simple test to determine the site of urinary-tract infection. Lancet, 2, 427.

Kaitz, A. L. (1961). Urinary concentrating ability in pregnant women with asymptomatic bacteriuria. Fournal of Clinical Investigation, 40, 1331.

Kerr, D. N. S. (1968). Paediatric Urology. p. 558 . Ed. by D. Innes Williams. Butterworth, London. 
King, E. J., and Wootton, I. D. P. (1956). Micro-Analysis in Medical Biochemistry, 3rd ed., p. 48. Churchill, London.

Metcoff, J. (1964). Renal regulation of body fluids. Pediatric Clinics of North America, 11, 833 (see p. 851).

Suki, W., Eknoyan, G., Rector, F. C., Jr., and Seldin, D. W. (1966). Patterns of nephron perfusion in acute and chronic hydronephrosis. Fournal of Clinical Investigation, 45, 122.

West, C. D., and Smith, W. C. (1956). An attempt to elucidate the cause of growth retardation in renal disease. American Fournal of Diseases of Children, 91, 460.
Winberg, J. (1959a). Determination of renal concentration capacity in infants and children without renal disease. Acta Paediatrica, 48, 318.

Winberg, J. (1959b). Renal function studies in infants and children with acute nonobstructive urinary tract infections. Acta Paediatrica, 48, 577.

Correspondence to Dr. W. S. Uttley, Department of Child Life and Health, University of Edinburgh, 17 Hatton Place, Edinburgh EH9 1UW.

The following articles will appear in future issues of this journal:

Review Article: Maternal Nutrition and Prenatal Growth. Experimental Studies of Effects of Maternal Undernutrition on Fetal and Placental Growth. By J. A. Brasel and M. Winick.

Comparison of 3 Methods Used in Assessment of Carbohydrate Absorption in Malnourished Children. By W. P.:T. James.

Food Antibodies in Serum-A Screening Test for Coeliac Disease. By F. Carswell and A. Ferguson.

Heights, Weights, and Skeletal Age of Jamaican Adolescents with Sickle Cell Anaemia. By M. T. Ashcroft, G. R. Serjeant, and P. Desai.

Growth and Bone Age of Juvenile Diabetics. By N. Evans, V. P. Robinson, and J. Lister.

Genetics of Atrial Septal Defect. By A. Sánchez Cascos.

Cytomegalovirus Mononucleosis in Chinese Infants. By W. Y. Lui and W. K. Chang.

Cushing's Syndrome in Childhood: Postoperative Management. By S. Raiti, D. B. Grant, D. I. Williams, and G. H. Newns.

Meningitis and Encephalitis Associated with Mumps Infection. A 10-Year Survey. By J. A. Johnstone, C. A. C. Ross, and M. Dunn.

Cellular Development of Some Human Organs Before Birth. By E. M. Widdowson, D. E. Crabb, and R. D. G. Milner.

Sodium, Calcium, and Magnesium Levels in Nails of Children with Cystic Fibrosis of the Pancreas. By P. J.

Leonard and W. P. Morris.

Effect of Folic Acid Treatment on Premature Infants. By P. M. M. Roberts, D. E. Arrowsmith, A. V. C. Lloyd, and M. E. Monk-Jones.

Night and Day Growth Hormone Levels During Treatment with Corticosteroids and Corticotrophin. By S. N. Pantelakis, C. A. Sinaniotis, S. Sbirakis, D. Ikkos, and S. A. Doxiadis.

Hepatic Glycogen Synthetase Deficiency: Further Studies on a Family. By J. R. W. Dykes and J. Spencer-Peet. 